\title{
A Coasean Approach to Bank Resolution Policy in the Eurozone $^{*}$
}

\author{
Gregory Connor \\ National University of Ireland, Maynooth
}

\author{
Brian O’Kelly \\ Dublin City University
}

\begin{abstract}
The Eurozone needs a bank resolution regime that can work across seventeen independent nations of diverse sizes with varying levels of financial development, limited fiscal coresponsibility, and with systemic instability induced by quick and low-cost deposit transfers across borders. We advocate a Coasean approach to bank resolution policy in the Eurozone, which emphasises clear and consistent contracts and makes explicit the public ownership of the externality costs of bank distress. A variety of resolution mechanisms are compared including bank debt holder bail-in, prompt corrective action, and contingent convertible bonds. We argue that the "dilute-in" of bank debt holders via contingent convertibility provides a clearer and simpler Coasean bargain for the Eurozone than the more conventional alternatives of debt holder bail-in or prompt corrective action.
\end{abstract}

\footnotetext{
* We would like to thank John Cotter, Gerry Dwyer, Trevor Fitzpatrick, Tom Flavin, Lars Frisell, Charles Goodhart, Stephen Kinsella, Philip Lane and seminar participants at the Dublin Economic Workshop and NUI Maynooth for helpful comments, and Lena Golubovskaja, Anita Suurlaht and Michael Wosser for research assistance. We wish to acknowledge support from the Science Foundation of Ireland under grant 08/SRC/FM1389.
} 


\section{Introduction}

This policy note considers various bank resolution mechanisms and evaluates them for use in the Eurozone. It is widely accepted that the Eurozone needs a fundamental restructuring of its bank resolution regime. The concurrent discussion of bank resolution changes in the USA provides the basis for most of the recent research literature. However, the flaws in the bank resolution regime in the Eurozone, and the range of feasible choices for improvement, differ sharply from those in the USA. The Eurozone's political-economic structure is quite different; it consists of seventeen independent nations with separate legal systems, varying levels of financial development, and limited fiscal co-responsibility. Cross-border credit flows and contagion make a regionally-controlled policy preferable, while political legitimacy is strongest at the national level. These monetary, political and regulatory features must be accommodated in bank resolution policy for the Eurozone.

Our analysis of bank resolution policy is founded on Coase's approach to optimal contracting in the presence of public externalities. Bank distress causes large public costs and, under Coase's analysis, the inefficiency associated with externalities can be eliminated by assigning clear property rights to the production of the externality. We argue that due to public-cost externalities the contingent right to contribute to bank distress should not be granted in any bank liability claim; the Eurozone-wide banking authority owns the right to prevent bank distress; where necessary this right should be allowed to override existing bank liability contracts in explicit, contingent circumstances. The bank resolution regime in the Eurozone should have this Coase-type contingent-ownership-right clearly expressed and simple to exercise.

We evaluate various bank resolution mechanisms from our Coasean perspective. We examine the strengths and weaknesses of bail-outs and bail-ins as resolution strategies for the Eurozone. We show that the successful US system of prompt corrective action (PCA) against weak commercial banks conforms well to our Coasean approach. However, we argue that PCA might not work reliably in the Eurozone due to the difficulties with fast and aggressive regulatory takeover of banks in a multinational system. We then consider contingent convertible bank debt. Contingent convertibility uses a policy of "dilute-in" rather than bailin of bank liability claimants. It is faster and is less legally fraught than bail-in, and can be instigated in the early stages of financial distress rather than in the final (bankruptcy) stage. It does not eliminate the need for a bankruptcy process, but lessens the reliance upon it. Contingent convertibility has the early intervention feature of PCA without its contractual and legal difficulties, which are particularly severe in a Eurozone context. Importantly from our perspective, contingent convertibility makes manifest the right of the central regulatory authority to block event-contingent bank liability claims which may contribute to bank distress and associated public costs.

Section 2 introduces our Coasean perspective on bank resolution policy. Section 3 evaluates bail-outs and bail-ins as resolution mechanisms for the Eurozone. Section 4 considers the alternative of prompt corrective action against weak banks. Section 5 discusses contingent 
convertibility of bank liabilities and outlines a proposal for extensive, flexible-form contingent convertibility of Eurozone bank liabilities. Section 6 concludes.

\section{Bank Distress and Government Intervention: A Coasean Perspective}

In most European countries, corporate bankruptcy is a slow and complex legal and managerial transfer of ownership and control over assets and liabilities. Particularly for banks, this protracted process generates large negative shocks to asset value. The preceding period of financial distress, when bank management, claimants and customers foresee possible bankruptcy, is also value-destroying. Crucially, bank distress and bankruptcy generate economy-wide externality costs. If all distress and bankruptcy costs were privately borne by the bank's direct claimants, there would be no public policy issue; banks and direct claimants could pre-negotiate the private-best solution, e.g., very low debt levels. In the case of banks, distress-and-bankruptcy-associated costs are spread widely across the regional or national economy. Banks are incentivized to hold high levels of debt, knowing that the benefits accrue to their direct claimants and the potential costs are spread publicly. Also, for very large banks, in the event of distress the public authorities are ex-post rationally disposed to provide taxpayer-funded support to the bank.

As shown by Coase (1960), inefficiencies generated by public externalities can be mitigated or (under restrictive conditions) entirely eliminated by assigning the right to control the externality explicitly to agents. This allows all concerned parties to contract efficiently among themselves, and thereby find a first-best solution to production and trade with externalities; see Varian (1994). Figure 1 provides a descriptive treatment of our Coasean perspective on bank distress and the associated public externalities. In Step 1, a bank issues liabilities, that is, contracts to pay cash later in exchange for cash now. The specific nature of the bank liabilities, whether retail deposits, saving accounts, secured or unsecured debt, is not critical at this point in the analysis. In Step 2, some random event, such as a sharp decline in asset values, has pushed the bank close to financial distress, but it has a contractual commitment to pay its liabilities; this cash outflow triggers financial distress. This financial distress, as a co-product, produces the public externality costs well-known to be associated with bank distress. 


\section{Figure 1}

Step 1: Contracting Event

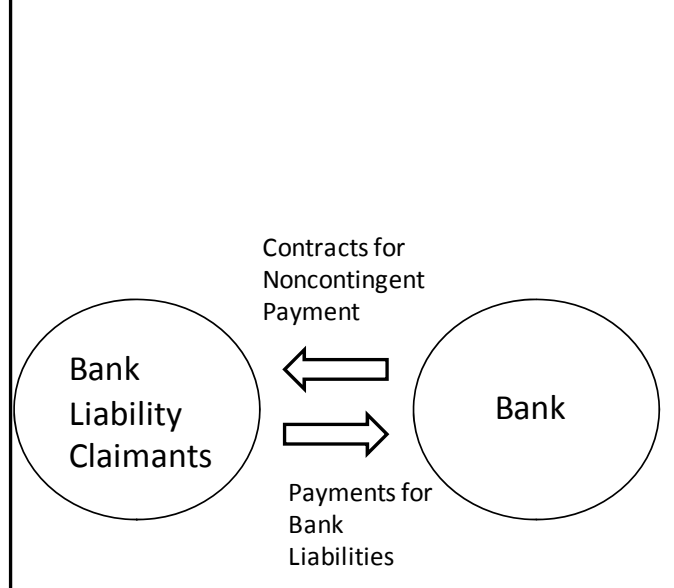

Step 2: Payment in Distress Event

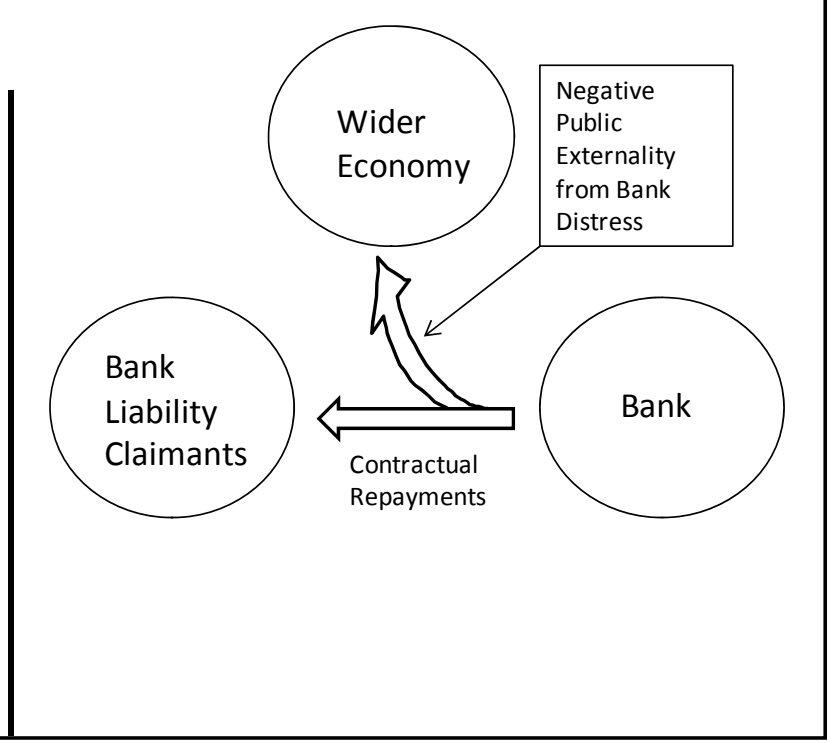

This contractual description provides the foundation for our approach. Using Coase's theorem, the social welfare inefficiency associated with the production of a public externality can be mitigated by assigning clear ownership of the externality to one party. In Figure 1, the public cost externality is shown as inextricably tied to the contractual repayments of bank liabilities in near-distress circumstances. Does the bank own the right to sell event-contingent claims which include economy-wide negative externalities as a by-product? There is no hard and fast answer but one possible answer is that the bank does not - we assume that its banking license does not include this ownership right. Therefore throughout our analysis we assume that the public authorities own the right to control public externality costs associated with bank distress. This perspective affects our interpretation of government intervention policies and in some cases also has substantive impact on policy recommendations.

Our Coasean perspective is not the only valid approach to bank resolution policy. An alternative is to define ownership rights in the conventional way, and allow for public interest over-ride of property rights to deal with externalities. Consider as an example this quote from a senior UK regulator, in discussing bondholder bail-in during bank resolution:

"Bail-in, like other resolution tools, involves some interference with property rights. But safeguards will apply which will ensure that no creditor is left worse off than they would have fared in a counterfactual insolvency. In keeping with that, it is important that bail-in follows the creditor hierarchy, secured claims are protected and netting arrangements are respected. And bail-in, like the other resolution tools, can only be used when it is necessary to do so in pursuit of clearly defined public interest objectives.” Andrew Gracie (2012)

Our policy interpretation is different. We treat resolution actions not as an interference with property rights but rather as an exercise of Coasean-type property rights: the regulator owns 
the right to prevent public externalities associated with bank distress. Any bank liability which has been sold to private claimants, promising payment in contingencies which may produce such externalities, is not a valid contract in this Coasean view. Such a contract has sold an event-contingent claim which the bank did not fully own (due to the attached externality) and so could not validly sell. This also invalidates the claim for compensation for resolution actions, since they are an exercise rather than an interference with property rights. This conclusion depends upon our Coasean assumptions - the assignment of ownership rights is not a given, it is a particular chosen assumption. So the approach suggested in the quote above is equally valid, but it is different from the one that we espouse for the Eurozone.

In Coasean theory, after an agent is assigned ownership of an externality all agents jointly trade efficiently. A production-trade equilibrium which efficiently accommodates externalities is called a Coasean bargain. In our application, in which the externality comes from the link between bank cash flows and the public costs of distress, finding a Coasean bargain involves finding a cost-efficient set of bank contracts which block the contingent cash flow payments shown in Figure 1. We have assigned ownership of the externality to the public authority. In theory, banks could purchase back from the public authority the right to pay these contingent cash flows and generate the externality costs of bank distress. We only consider the corner-solution case in which banks do not purchase back the right to create economy-wide distress.

Varian (1995) describes a simple model of production and exchange in an economy with a public externality and compares a Coasean solution, in which ownership of the externality is assigned to one agent and then agents bargain over its production, and a Pigouvian solution (see Pigou (1920, chapter 9)), in which the government imposes taxes on the externality to control its production. Varian shows an equivalence mapping between these two approaches to controlling the externality. In particular, given that the bargaining mechanism in the Coasean solution is efficient, and similarly for the taxation system in the Pigouvian solution, the two approaches both produce a Pareto-efficient production and exchange equilibrium, which differs only in its allocation of wealth across agents. Varian's classic result is technically interesting, but not particularly relevant to our argument. Varian assumes no transactions cost, no information asymmetries, and no bargaining-related inefficiencies. In our application the Coasean approach is preferable to the more conventional Pigouvian approach due to the particular political-institutional-regulatory nature of bank resolution problems of the Eurozone.

\section{Bail-outs and Bail-ins in Bank Resolution}

Diamond and Dybvig (1983) provide a classic analysis of bank runs and the contribution of government bail-outs (or government-funded deposit insurance) as a resolution device. They consider a bank with lending assets which have low value if liquidated early at firesale prices and higher value if held to maturity. Bank liability claimants (in their simple model, depositors only) have the right to withdraw their claims at any time. In the absence of government-funded deposit insurance, the model has multiple equilibria: if depositors conjecture that all other depositors will withdraw early, sacrificing interest to protect their 
principal value, then they also will withdraw early and the bank will be liquidated at firesale prices. If depositors conjecture that all others will not withdraw early, then the bank will survive. Suppose now instead that the government commits to bail out all depositors with fiat money - if there is a run by depositors, those who join the run will be redeemed in full with (possibly diluted-real-value) fiat money; those who wait will receive the same payment with interest. The government-funded insurance makes joining a bank run irrational irrespective of others' behaviour and the bank-run equilibrium disappears. The insight in the DiamondDybvig model is written into US bank resolution code - the FDIC has an explicit facility to request unlimited funds from the US Treasury (see Spong (2000, p.65)). The existence of this unlimited facility, paradoxically, eliminates the possibility that it will be called upon, and the FDIC insurance fund continually runs a modest surplus (see FDIC (1998, Appendix 3)).

De Grauwe (2011) extends the Diamond-Dybvig model to the case of a currency union in which depositors have the ability to withdraw deposits from one member state's banks and transfer cheaply to banks in other member states. In the event of a domestic run on banks, a member national government can provide a bank bail-out using sovereign borrowing but not using fiat money, which is centrally controlled. The pressure on sovereign credit quality from sovereign-funded bank bail-out expenditures can amplify the macroeconomic credit withdrawal shock of deposit flight, worsening rather than eliminating the bank-run bad equilibrium. The initial causality linking sovereign credit quality and domestic bank deposit flight can run in either direction. So for example in the case of Ireland, deposit flight began in late 2008 when corporate and inter-bank depositors realized the dire state of Irish banks; this was followed by a very expensive sovereign-funded bank bail-out effectively bankrupting the sovereign, which induced even more deposit flight, a credit crunch, and a deep macroeconomic slump, and eventually the effective receivership of all domestic Irish banks and the sovereign under IMF-EU-ECB auspices. Conversely, in the case of Greece, the Greek domestic banking sector was run conservatively prior to its financial crisis, but it was revealed in mid-2009 that the national income accounts had been kept fraudulently and in fact the sovereign was more deeply in debt than realized. This led to massive deposit flight from its domestic banks, contributing to the ongoing deep recession, and ending with both sovereign and banking sector in deep insolvency. A similar sovereign - banking sector negative feedback mechanism is also evident in Spain and Portugal. In addition to the compelling case-by-case evidence of banking sector - sovereign feedback there is also evidence from bank and sovereign credit default swap (CDS) spreads. In a panel and time series analysis of weekly sovereign CDS spreads of eighteen European countries, including eleven Eurozone members, Dieckman and Plank (2012) show that the cross-section of sovereign CDS spreads is significantly related to country-specific growth in domestic banking assets over the pre-crisis period, and that the joint panel-time-series of CDS spreads depends significantly on the contemporaneous relative returns to a domestic financial services industry index. Acharya, Dreschler and Schnable (2011) build a theoretical model of interdependent banking-corporate-sovereign sectors in which the sovereign uses sovereign borrowing and tax proceeds from the corporate sector to bail out the banking sector, so that banks can lend efficiently to the corporate sector. They apply their model empirically to sovereign and individual-bank CDS spreads and provide compelling evidence of feedback 
between domestic bank sector and sovereign bond credit quality in Western European countries.

This interaction between bank bail-outs, sovereign creditworthiness, banking sector distress and lending, macroeconomic shocks, and cross-border deposit flight has made the Eurozone banking crisis more virulent than in the USA. The ongoing regional recession, destabilizing credit flows and joint sovereign-banking distress have been so severe that they have endangered the continued existence of the Euro currency. It is clear that sovereign-funded bank bail-outs are not an appropriate resolution mechanism for the Eurozone.

An alternative to sovereign-funded bail-outs are bail-outs funded by pooled Eurozone-wide funds. However there are substantial difficulties with Eurozone-funded bail-outs of member states' banks. Bail-outs of bank liability holders create moral hazard for bank owners and other bank claimants. They weaken the incentives for monitoring by non-equity claimants, and increase the incentives for risk-taking by managers and owners. In the case of a multinational resolution regime there is an additional level of moral hazard at the national level from bail-outs. It is now widely accepted that bank bail-outs other than explicit deposit insurance for retail accounts should be excluded from the bank resolution system. Best practice is to have in place deposit insurance for retail deposit balances below a maximum, and a no-bail-out provision for other bank claimants, and this is the likely future configuration in the Eurozone.

A "bail-in" is any resolution mechanisms that forces debt holders to absorb losses. From our Coasean perspective it is key to distinguish between bail-ins that maintain the ex-ante contractual priority ordering of bank liabilities and those that do not. Bail-ins which maintain the priority ordering of liabilities require bankruptcy, since equity has the lowest priority of all corporate liabilities. The problem with this type of bail-in is that bankruptcy works poorly as a resolution mechanism for banks. A key problem with standard bankruptcy is the cloud that impending bankruptcy puts on the bank's ability to enter into reliable contractual relationships with liquidity and credit providers. For some individual sovereign states it is possible to envision a working bail-in system based on a very fast and efficient bankruptcy process, but this does not seem a feasible prospect for the entire seventeen-nation Eurozone.

Bail-ins that alter the priority of claims, leaving the bank outside bankruptcy but forcing debt holders to accept losses, can be a necessary response to particular ex-post circumstances when better resolution mechanisms are not available. They can be justified when the sovereign is forced to bail out equity holders at a cost greater than the total value of multiple layers of debt, in order to keep the bank functioning outside bankruptcy and prevent the spread of economy-wide financial distress. The subordinate bondholder bail-in subsequent to the Irish bank bail-out of 2009-2010 is a prime example of a justified bail-in without bankruptcy. In early 2009, it became clear that several Irish domestic banks were deeply insolvent, with unaccounted-for losses greater than all their equity and subordinate debt liabilities combined. In order to keep its banking system functioning, and retain access to ECB liquidity support, the Irish sovereign bailed out Irish banks by injecting $€ 60$ billion of new equity. Subsequently, subordinate bondholders were forced to accept losses even though 
the banks were never officially declared insolvent; existing shareholders suffered nearcomplete dilution but did not formally relinquish their claims. Given the need for a quick response to the failed system in existence at the time, this ad hoc priority re-ordering was a justified action. However, this type of ad hoc bail-in with priority-reordering leads to ambiguity in contractual rights and is not a good foundation for future resolution policy.

\section{Prompt Corrective Action}

A different approach to the bank resolution problem has been implemented quite successfully in the USA, particularly following enabling legislation in 1991 which increased the regulator's power over banks approaching financial distress. A policy known as prompt corrective action (PCA) is a regulatory system of fast, pre-emptive intervention into troubled banks by the regulatory authority, including extensive control over bank assets and management, as soon as impending bank distress becomes apparent.

In the USA, the inability of the regulatory authorities to quickly and successfully resolve large US dealer banks was a central component of the 2007-2008 credit-liquidity crisis. (At the time of the US crisis, most of the institutions under threat did not have banking licenses and so were not within the direct purview of the PCA regulatory code.) The crisis spread widely and deeply into the US and global banking sector, impacting on all types of financial services firms, including non-dealer commercial banks. However, even during the height of that crisis, the US bank resolution system of prompt corrective action continued to work reasonably well for resolving distressed non-dealer US commercial banks. During the troubled period January 2008 - August 2012, the FDIC resolved 454 troubled banks using PCA, and in only $5.2 \%$ of these resolution actions was there no buyer, i.e., bank closure. The USA has a large number of small banks, which partly accounts for the large number of resolutions, but not all of these distressed banks were small institutions. The list includes Washington Mutual Bank with accounting assets of \$307 billion, for which the FDIC resolution action was completed in only 15 days.

PCA is compared to bankruptcy in Figure 2. Figure 2a shows a classic one-period payoff diagram for a corporation with a single debt issue with end of period payment of $€ 100$. If asset value falls below $€ 100$, firm ownership and management control passes to the bondholders, and the shareholders loses any claim to corporate assets. Above this value, bondholders receive $€ 100$ and shareholders retain ${ }^{1}$ ownership and management control over corporate assets. PCA is depicted in Figure $2 \mathrm{~b}$ - if asset value declines to the region of financial distress then the regulator (in the US case, the FDIC) has the legal right and responsibility to oversee many aspects of management of the bank, promptly resolve balance sheet and/or management problems, and close, merge or re-open the bank according to the regulator's own decision in the public interest. As part of PCA, the regulator has the right to force a critically undercapitalized bank into receivership. The resulting claim ambiguity is depicted by the wiggly lines in Figure 2b. The FDIC also has access to an unlimited supply of

\footnotetext{
${ }^{1}$ Retaining ownership/control has no benefit to shareholders in this one-period model, but extending the model to multiple periods complicates the graphical treatment without aiding intuition. The graphs are merely descriptive.
} 
US dollar funds to inject into a failing bank, if that is determined to be in the public interest. See Spong (2000, pp. 85-144) for an overview of PCA regulations in the USA.

\section{Figure 2: Bank Liability Payoffs Under Standard Bankruptcy and PCA}
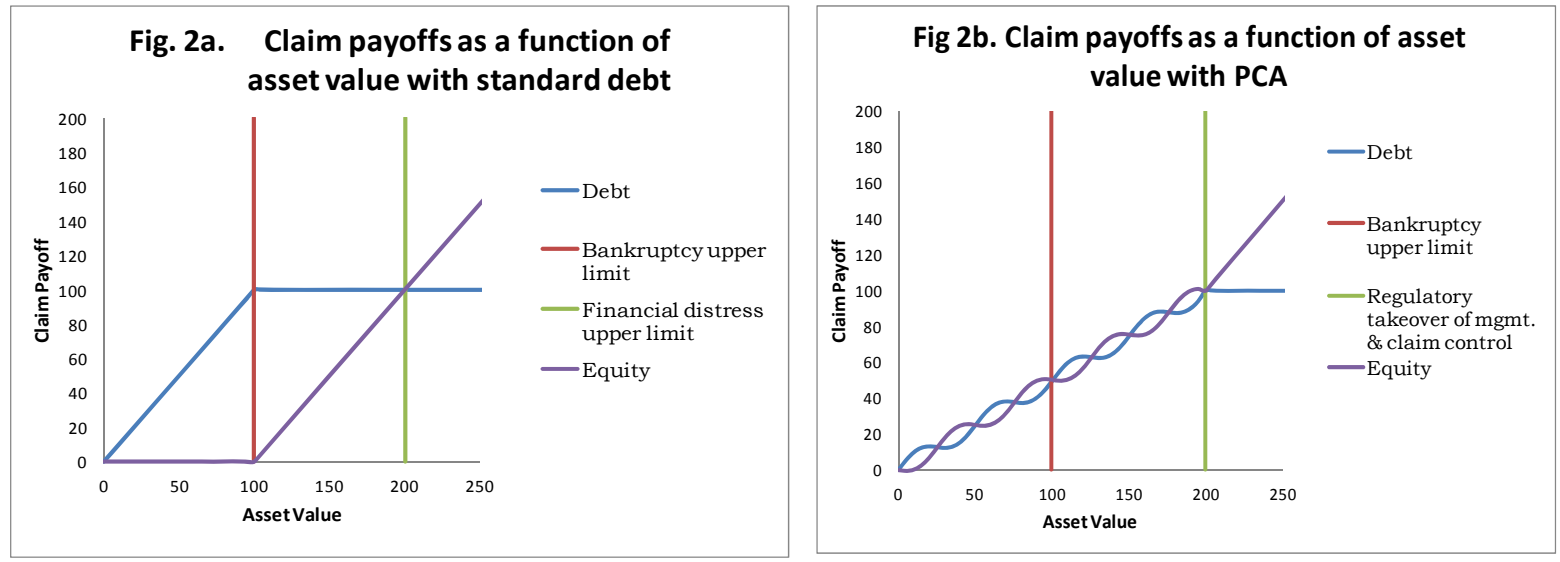

Superficially, the policy of PCA can be perceived as an abrogation of shareholder and bondholder property rights, since ownership/control passes to an outside agent before bankruptcy. The ownership/control rights taken by the regulator in PCA exceed even those of shareholders in a standard setting, since the regulator has some authority to effectively reorder or extinguish debt and equity claims in the public interest by forcing the bank into receivership, a power not given to shareholders or bank management. PCA sidesteps the slow working out of liabilities in bankruptcy by giving the regulator the legal right to pre-emptive control.

It is useful to consider PCA from a Coasean perspective. Bank shareholders and bondholders have purchased the right to their bank claims, including managerial control of the firm (passing from shareholders to bondholders at bankruptcy). The key Coasean question: does that property right include the right to instigate a banking crisis impacting the wider economy? Put more dramatically, who owns the control right to instigate or prevent a banking crisis? If bank liability holders do not own this right, then there is a justification for the regulator being given an explicit, pre-stated right to take over and run the bank in the public interest once the bank approaches financial distress. In this case, using Coase's argument, it is efficient if shareholders and bondholders can only purchase contingent claims to ownership and control, contingent on the bank remaining out of financial distress. If the bank approaches financial distress, they have no (or explicitly limited) ownership and control rights. The state owns ${ }^{2}$ the right to prevent a banking crisis and PCA is the state exercising this property right. PCA is justified by this Coasean perspective.

PCA embodies the Coasean principal that the regulator has a preemptive right over private contracts involving a bank if these contracts endanger bank distress and the associated public costs. However, PCA does this in a way that is not ideally suited to the Eurozone politicaleconomic and regulatory environment. PCA by its nature requires a rock-solid legal foundation. Legally establishing reliable and consistent property rights for PCA across all

\footnotetext{
${ }^{2}$ Speaking strictly from a Coasean perspective, bank claimants should be freely permitted to purchase this right from the state, but it is likely to be prohibitively expensive.
} 
seventeen independent nations of the Eurozone seems overly ambitious. The problem, which does not apply equally in the USA, is that Eurozone PCA relies on iron-clad authority for very fast regulatory intervention in any bank across a large collection of independent nations.

PCA also relies heavily on a regulator who can successfully oversee troubled banks during the PCA engagement. This requires a regulator with technical expertise, and fast, competent decision-making capability. The FDIC has shown that it is capable of making PCA work reasonably well (except possibly for the largest dealer banks ${ }^{3}$ ). It is unlikely that all of the individual national bank regulators across the Eurozone could be relied upon to enact PCA competently. The poor behaviour of some national financial regulators, e.g., the Irish financial regulator during the 2000 - 2007 period, shows how badly individual national regulators can perform in some circumstances. For any chance of success, PCA authority would need to be vested in a single cross-region regulator. Such a centralization of power in a multinational federation gives rise to its own challenges in terms of the ability to intervene quickly and aggressively in troubled banks. Consider, for example, the PCA intervention by the FDIC into eleven troubled banks in Nevada during the period 2008-2012; these eleven banks had a total of $\$ 316$ billion of assets. The FDIC had to make quick decisions about the amount of resources to inject into these banks, impose changes in bank lending strategy, negotiate as to which of the banks should be promptly forced into acquisition by other banks (possibly headquartered outside the state), and which banks to close. These prompt decisions by the regulator might have long-term impact on the regional economy. State and regional political authorities in the US have almost no input into these important decisions. Consider now in contrast a hypothetical future event in which similar widespread bank distress impacted a region or nation-state in the Eurozone. Would the national political authorities allow a foreign-based regulator to promptly and aggressively take over their national or regional banking system and make key decisions about this industry, decisions which would also affect the long-term industrial structure and growth rate of the national or regional economy? Would other Eurozone states concur if the regulator decided that the situation required a large capital injection from pooled resources? PCA might require a system of centralized political control which the Eurozone does not have and does not want.

\section{Contingent convertible bank liabilities}

An exciting and innovative approach to the bank resolution problem, first proposed by Flannery (2002), is contingent convertibility of bank debt. Figure 3 illustrates how this works. A trigger point tied to asset value (such as an equity/assets ratio) is established at or above the region of financial distress. When the ratio decreases to the trigger point, a proportion of debt is automatically converted, via a pre-existing contractual feature, into common equity at prespecified conversion terms. Figure 3 assumes that $50 \%$ of the debt is convertible and $50 \%$ nonconvertible. The trigger event transforms a proportion of the bank's debt liability into common equity. The pre-existing shareholders and former bondholders then share equity

\footnotetext{
${ }^{3}$ As mentioned above, at the time of the 2007-2008 US crisis many of the financial institutions at risk were outside the scope of the FDICs authority since they did not have banking licenses. Hence it is not clear whether PCA would work successfully for a large broker-dealer institution; its capability is untested for this task. See Duffie (2010a) for a detailed analysis of the fast-paced distress and failure dynamics of large dealer banks.
} 
ownership. If asset value subsequently rises, pushing the ratio above the trigger point, the conversion does not reverse. Unlike the management/ownership transfer associated with bankruptcy, share dilution via debt conversion is an external rather than internal corporate event. Management remains in place and continues to serve the needs of shareholders (the changing composition of shareholders need not impact on this objective).

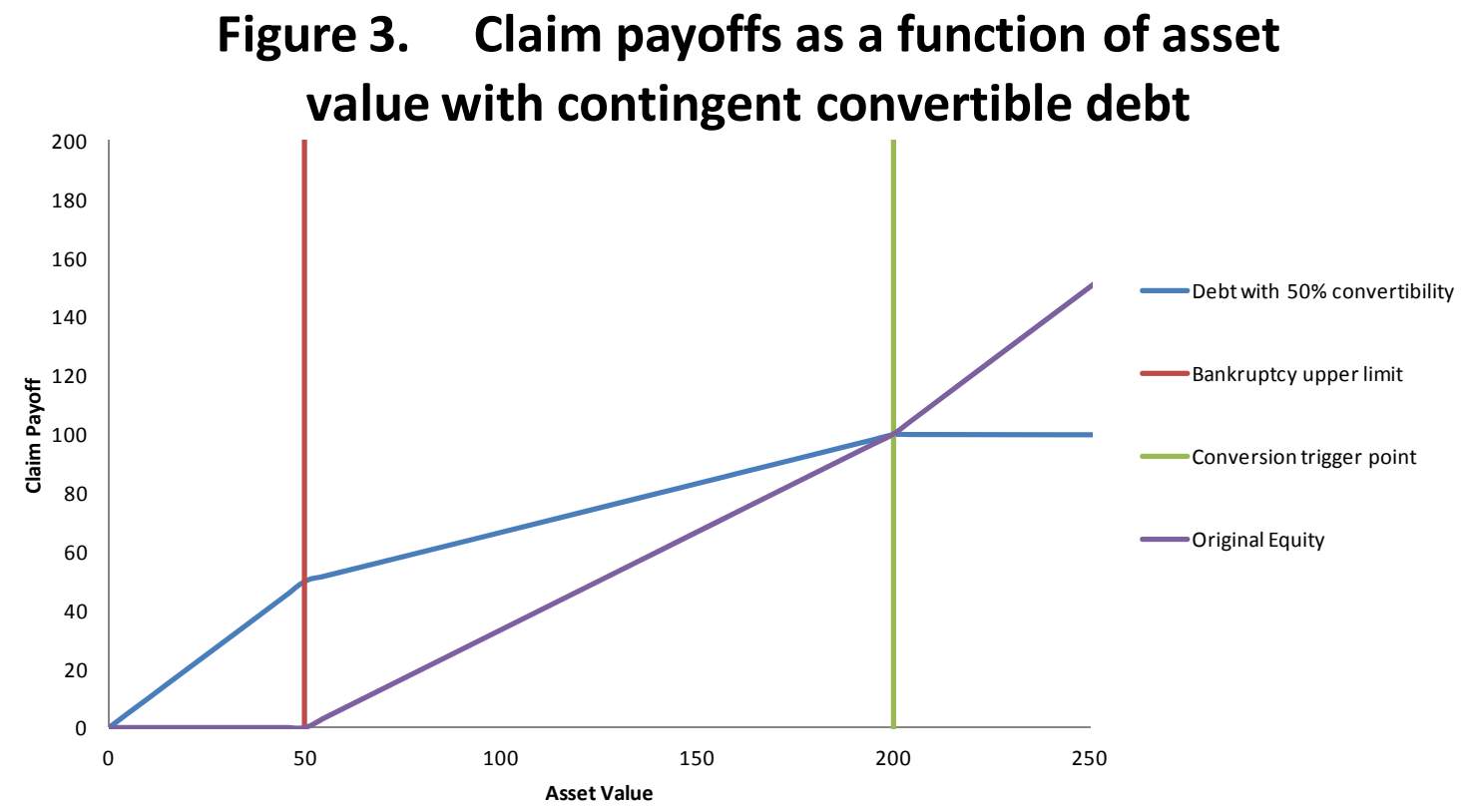

There are a number of trade-offs that need to be addressed in designing a contingent convertible debt regime:

- The impact on credit growth and bank cost of capital from contingent convertibility of bank debt

- How the scheme incentivizes or dis-incentivizes private monitoring of bank risktaking by shareholders and other bank liability claimants

- The impact on bank management behaviour

- The quality, timeliness and possible manipulation of accounting figures for use in trigger measures

- The balance between triggering conversion too frequently or infrequently.

Contingent convertibility of debt alters the incentives of shareholders and bondholders. By making bond payments contingent upon bank safety, contingent convertibility increases the bank monitoring incentives of bondholders relative to a system with an implicit bail-out for bondholders. This type of private-sector monitoring is a particularly valuable contribution in the Eurozone, where the quality of bank regulation is likely to vary across the region.

Depending upon their features, contingent convertible bonds in the bank's capital structure can increase or decrease the risk-taking incentives of shareholders.

There have been a variety of specifications suggested for contingent convertible bonds. One design issue is the choice of the metric used to measure impending financial distress. Flannery (2009) argues (in the context of the US too-big-to-fail problem) that market-price- 
based triggers are superior to those using accounting ratios. Market prices capture newer information and are less subject to manipulation by bank management. Many of the banking institutions at risk in the Eurozone have illiquid or non-traded equity, so that the market prices of their shares are unreliable or non-existent. In the context of a strategic policy for the Eurozone, the use of market prices for trigger metrics is not feasible.

Duffie (2010b) notes that in December 2008, after the Lehman Brothers bankruptcy and during the depth of the US credit crisis, Citigroup reported an accounting equity-to-assets ratio of $11 \%$, which is well above any hypothetical trigger value for contingent convertibility. Duffie points out that this mostly reflected the role of intangible assets particularly tax-loss carry-forwards, which boosted the book value of equity while readily available stockholder equity was actually dangerously low. He suggests that tangible equity-to-assets (which subtracts intangible assets from both sides of the balance sheet) is preferable as a trigger measure for contingent convertibility.

McDonald (2011) considers the trade-off between having a conversion trigger which acts too readily, as a by-product distorting incentives and increasing the cost of debt capital, and a trigger which acts too slowly, potentially leading to economy-wide bank distress. In the context of the US too-big-to-fail problem he argues for a dual trigger, in which contingent convertibility is triggered only if both a firm-specific risk measure is exceeded (such as a minimum equity-to-assets ratio) and a market-wide measure tied to a banking sector equity index has dropped by a pre-specified amount. The particular dual-trigger suggested by McDonald has no relevance for the problems of the Eurozone - as a hypothetical example, the Portuguese banking sector could collapse in regional distress without having any notable impact on Eurozone-wide banking indices. It is not obvious how one could design a dualtrigger system appropriate to the particular, and very different from the US, bank distress and resolution problems of the Eurozone.

Another key design feature is the conversion ratio used for transforming debt claims into equity ownership after the trigger event. A dilutive conversion ratio gives bondholders a lower-value claim with conversion than without, whereas an anti-dilutive conversion ratio gives bondholders an increased-value claim, detracting from the claim of pre-existing shareholders. The conversion ratio affects the incentives of bondholders and shareholders to monitor and control bank risk, and the incentives to manipulate the conversion measure to hinder or encourage a trigger event. Sundaresan and Wang (2012) propose that the conversion ratio be set so that the trigger event is neutral in terms of dilution. Calomiris and Herring (2011) propose a strongly dilutive conversion ratio, in order to incentivize bank management and shareholders to avoid financial distress. Pennachi, Vermaelen and Wolff (2011) suggest a strongly dilutive conversion ratio combined with a call option feature allowing individual shareholders to repurchase the debt instruments, thereby avoiding the dilution of their equity ownership. This effectively transforms the contingent convertible bond into a combination of a contingently-callable bond and an equity rights offering. See von Furstenberg (2011) for a review of contingent convertible design features. 
The optimal design of contingent convertible securities requires a delicate balance between minimizing the impact on bank cost of capital, providing appropriate incentives to shareholders, bondholders and management, and providing adequate protection against bank distress. It is difficult to forecast exactly what long-term impact the various proposed security designs might have on banks' overall cost of capital and on their continued, reliable access to funding. In the context of the Eurozone, one security design might not suit all circumstances across the member states. We suggest a flexible approach, in which individual banks working with their national regulators can choose the bond features they feel are most suitable, while the Eurozone regulator imposes minimal region-wide requirements. This allows for a competitive environment in which the best-performing security designs could be replicated and spread over time. Each bank's chosen conversion features across bank claimants, chosen dilution ratios, and priority order of conversion across claims, could be flexibly allowed as long as the chosen features do not interfere with the potential conversion of the bank's entire non-exempt cash flow liabilities into common equity.

From a Eurozone perspective, two key advantages of contingent convertibility are legal clarity and regulatory simplicity. Relative to the contractual/legal difficulties of bail-ins and prompt corrective action, enforcing contingent convertibility is very straightforward. It requires Eurozone-level banking rules mandating that bank debt issues have clear and explicit convertibility features in their contracts at issuance. Importantly, at the date on which convertibility takes place, there is no uncertainty about the legal rights of all parties and no impact on the other contractual obligations of the bank.

The Eurozone needs to eliminate "grey area" bank liabilities which are neither explicitly insured nor feasibly resolvable without bail-out or bankruptcy. All unsecured bank liabilities other than very short-term ones should either have explicit insurance coverage (such as retail deposits below a maximum account balance) or explicit contingent convertibility.

\section{Summary}

This policy note offers suggestions on bank resolution strategy for the Eurozone, taking account of the region's unique political-economic and regulatory environment. The contractual, political and regulatory difficulties associated with bank resolution are daunting in the Eurozone. Due to the high risk of regional contagion the Eurozone requires a unified resolution system, but it is a federation of seventeen independent states with separate legal systems, limited fiscal co-responsibility, and varied levels of financial market development. Political legitimacy lies mostly at the national level, but bank resolution policy and implementation must be centralized.

We argue that the bank resolution regime in the Eurozone should be built on Coasean principles - it should be made clear that, due to the public externalities associated with banking crises, the centralized bank regulatory authority owns the contingent right to prevent bank distress. Private contracts entered into by banks may not hinder this contingent right of the regional public authority. 
We evaluate various approaches to bank resolution. Bail-ins which respect claim priorities are not a solution in the Eurozone since the bankruptcy system across seventeen nations will not have the speed and effectiveness necessary to very quickly resolve problem banks. Bailins which do not respect claim priority create contractual ambiguity whereas the Eurozone needs clarity and simplicity. The reasonably successful US system of prompt corrective action (PCA) against distressed banks makes sense within our Coasean framework. However, PCA is not well suited to the Eurozone's political-economic and regulatory environment. The Eurozone needs a banking crisis defence system with the strengths of PCA, in particular its early intervention feature and its embodiment of the regulator's preemptive right over private contracts to prevent crises, without its weaknesses, in particular PCA's difficult legal, political and managerial implementation.

Contingent convertibility takes a different approach from bail-out, bail-in or PCA, one which is more compatible with the political-economic and regulatory environment in the Eurozone. It essentially replaces bail-in with "dilute-in": bank debt must be issued with an explicit contractual feature mandating that the debt is converted to common equity when a specified risk measure breaches a trigger value. Contingent convertibility conforms well to our Coasean approach since these securities eliminate state-contingent cash outflows for those states of nature where debt payments might trigger bank distress. From our Coasean perspective, contingent convertible debt seems an efficient security design to block the public externality of bank distress in the Eurozone. 


\section{Bibliography}

Acharya, V.V., I. Drechsler and P. Schnabl (2011). 'A Pyrrhic Victory? - Bank bailouts and sovereign credit risk', New York University Stern School of Business Working Paper.

Calomiris, C.W. and R.J. Herring (2011). 'Why and how to design a contingent convertible debt requirement', Working Paper, revised Nov. 2011.

Coase, R.H. (1960). 'The problem of social cost', Journal of Law and Economics, 3: 1-44.

De Grauwe, P. (2011). 'The governance of a fragile Eurozone,' Centre for European Policy Studies Working Paper \#3026, May.

Diamond, D.W. and P.H. Dybvig (1983) 'Bank runs, deposit insurance, and liquidity,’ Journal of Political Economy, 91 (3): 401-419.

Dieckmann, S. and T. Plank, (2012). 'Default risk of advanced economies: An empirical analysis of credit default swaps during the financial crisis', Review of Finance, 16 (4): 903934.

Duffie, D. (2010a). How big banks fail - and what to do about it, Princeton University Press, Princeton, New Jersey.

Duffie, D. (2010b). 'A contractual approach to restructuring financial institutions,' in Ending Government Bailouts as we Know Them, edited by G. Shultz, K. Scott, and J. Taylor, Hoover Institution Press, Palo Alto, California, pp. 110-124.

Flannery, M. (2002). 'No pain no gain? - Effecting market discipline via reverse convertible debentures’, University of Florida Graduate School of Business Administration Working Paper.

Flannery, M. (2009). 'Stabilizing large financial institutions with contingent capital certificates’, University of Florida Working Paper October 5, 2009.

Gracie, A. (2012). ‘A practical process for implementing a bail-in resolution power', Bank of England speech given at the British Bankers Association, Sept. 2012.

McDonald, R.L. (2011). 'Contingent capital with a dual price trigger,' Journal of Financial Stability.

Pennacchi, G., T. Vermaelen and C.Wolff (2010). 'Contingent Capital: The case for COERCs’, Universite de Luxembourg LSF Working Paper No. 10-08.

Pigou, A.C. (1920). The economics of welfare, $4^{\text {th }}$ edition, Macmillan and Company Ltd., London.

Spong, K. (2000). Banking regulation: Its purposes, implementation and effects, Federal Reserve Bank of Kansas City, $5^{\text {th }}$ Edition.

Sundaresan, S. and Z. Wang (2010). 'Design of contingent capital with a stock price trigger 
for mandatory conversion’, Federal Reserve Bank of New York, Staff Report No. 448.

Varian, H. (1994). 'A solution to the problem of externalities when agents are wellinformed', American Economic Review, 84 (5): 1278-1293.

Varian, H. (1995). 'Coase, competition and compensation', Japan and the World Economy, 7: 13-27.

von Furstenberg, G.M. (2011). 'Concocting marketable cocos', Hong Kong Institute for Monetary Research Working Paper No. 22/2011. 